\title{
A gravity model for the lithosphere in western Kenya and northeastern Tanzania
}

\author{
Andrew A. Nyblade and Henry N. Pollack \\ Department of Geological Sciences, University of Michigan, Ann Arbor, MI 48109, USA \\ (Received June 12, 1991; revised version accepted March 30, 1992)
}

\begin{abstract}
Nyblade, A.A. and Pollack, H.N., 1992. A gravity model for the lithosphere in western Kenya and northeastern Tanzania. Tectonophysics, 212: 257-267.

We present a new gravity model for the lithosphere beneath the Kenya Rift Valley, the Mozambique Belt, and the Tanzania Craton in western Kenya and northeastern Tanzania. The Kenya Rift lies within the eastern branch of the extensive Cenozoic East African Rift System and has developed almost entirely in the Pan-African Mozambique Belt about 50 to $150 \mathrm{~km}$ east of the exposed margin of the Archean Tanzania Craton. The gravity field over western Kenya and northeastern Tanzania is characterized by a long-wavelength Bouguer anomaly. We propose that this anomaly has two components: (1) a "rift" signature, deriving from a shallow rift basin, a lower crustal intrusion and a low-density zone in the mantle lithosphere localized beneath the rift axis, and (2) a "suture" signature, arising from a crustal root along the boundary between the Mozambique Belt and Tanzania Craton and higher density crust in the mobile belt above part of the crustal root. Two lines of reasoning support our interpretation:

(1) Recent geological studies of the Mozambique Belt in Kenya and Tanzania suggest that it is a continent-continent collision zone, and continent-continent collision zones worldwide commonly exhibit a characteristic gravity anomaly.

(2) The long-wavelength Bouguer anomaly has at least two minima, one over the craton-mobile belt boundary, and one or more over the rift valley. Corroborative evidence for our interpretation of the gravity field is provided by recent seismic investigations.
\end{abstract}

\section{Introduction}

The East African rift valleys belong to a major continental rift system extending southward from the Afar region in Ethiopia to the southern end of Lake Malawi. Parts of this rift system have been studied in some detail, most notably the Kenya Rift (also known as the Gregory Rift). The Kenya Rift extends across western Kenya in a roughly $\mathrm{N}-\mathrm{S}$ direction and terminates in northeastern Tanzania (Fig. 1).

Among the many investigations of the Kenya Rift are several gravity studies (Bullard, 1936;

Correspondence to: A.A. Nyblade, Department of Geosciences, Deike Building, Pennsylvania State University, University Park, PA 16802, USA.
Masson-Smith and Andrew, 1962; Sowerbutts, 1969; Girdler et al., 1969; Baker and Wohlenberg, 1970; Searle, 1970; Khan and Mansfield, 1971; Darracott et al., 1972; Darracott, 1974; Girdler, 1975; Wohlenberg, 1975; Fairhead, 1976; Swain and Khan, 1978; Fairhead and Walker, 1979; Swain et al., 1981; Bechtel et al., 1987; Ebinger et al., 1989). Gravity measurements in and around the rift valley delineate a long-wavelength Bouguer gravity anomaly over western Kenya and northeastern Tanzania (see Fig. 4 for examples). Gravity models developed by many of these investigators suggest that a possible explanation for this anomaly is low-density (hot) material in the upper mantle beneath the rift and its western shoulder.

As we discuss in more detail below, the Kenya Rift lies in a region of complex Precambrian 


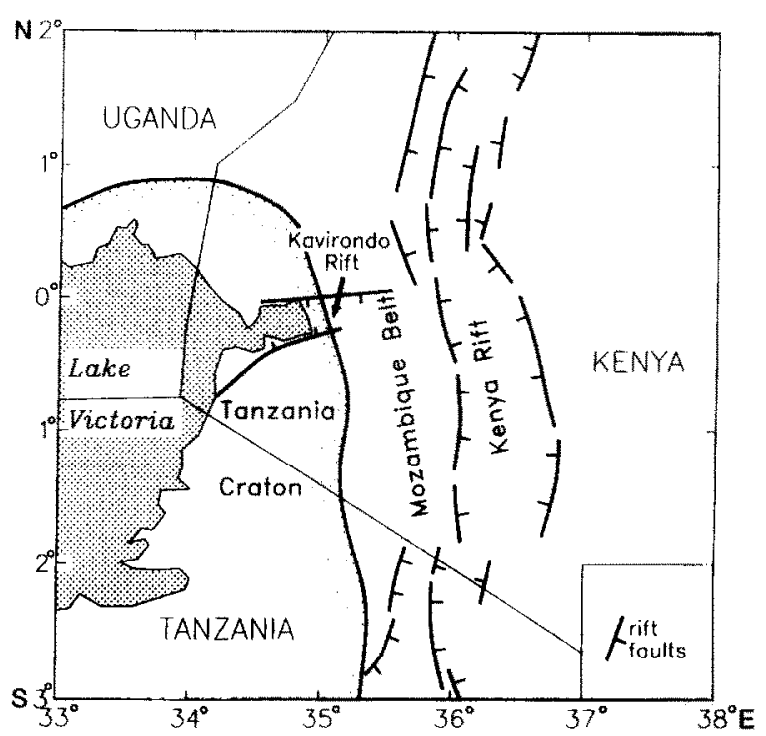

Fig. 1. Simplified tectonic map of western Kenya and northeastern Tanzania showing Precambrian terrains and major Cenozoic rift faults.

geology. The rift has developed almost entirely in the Pan-African Mozambique Belt about 50 to $150 \mathrm{~km}$ east of the exposed margin of the Archean Tanzania Craton (Fig. 1). Shackleton (1986) and Key et al. (1989) interpret the Mozambique Belt as a late Precambrian continent-continent collision zone. If this interpretation is correct, then it has important implications for modeling the gravity field over western Kenya and northeastern Tanzania. Elsewhere it has been demonstrated that crustal structures developed within Archean-Proterozoic sutures give rise to characteristic Bouguer gravity anomalies. Therefore, a significant portion of the observed Bouguer gravity anomaly over western Kenya and northeastern Tanzania may arise from crustal structures along the craton-mobile belt suture.

The possible gravimetric effects of Precambrian crustal structures along the craton-mobile belt boundary were not included in earlier gravity studies. In this paper, we reinterpret the longwavelength Bouguer gravity anomaly over western Kenya and northeastern Tanzania, proposing that this anomaly is comprised of two components: (1) a "rift" signature, deriving from crustal structures and a low-density zone about $100 \mathrm{~km}$ wide in the mantle lithosphere beneath the rift axis, and (2) a "suture" signature, arising from crustal structures developed along the boundary between the Mozambique Belt and the Tanzania Craton.

\section{Geology}

The Kenya Rift is a well defined graben about $70 \mathrm{~km}$ wide and several hundred kilometers long. Most of the rift floor and shoulders are covered with thick sequences of Tertiary lava flows and volcaniclastic units. The earliest faulting and volcanic eruptions are thought to be contemporaneous, starting at about $20-25 \mathrm{Ma}$ in the northern section of the rift, and somewhat later in the southern part of the rift (Baker et al., 1972; Ebinger, 1989). The main rift faults are shown in Figure 1. Most are roughly parallel to the eastern margin of the Tanzania Craton, but some faults deviate from the general $\mathrm{N}-\mathrm{S}$ trend and cut the eastern margin of the craton in an $\mathrm{E}-\mathrm{W}$ direction.

Development of the Mozambique Belt was polycyclic. The oldest dates, at about $1200 \mathrm{Ma}$, have been obtained from the western section of the mobile belt along the craton margin; the youngest ages, at about $450 \mathrm{Ma}$, are from areas to the east of the Kenya Rift (Cahen et al., 1984). Shackleton (1986) and Key et al. (1989) cite three main lines of reasoning that suggest a collisional history for the Mozambique Belt: (1) altered shelf-sediments can be traced across the entire width of the orogen; (2) deformation is complex and intense and is associated with high-grade metamorphism; and (3) structures are mainly recumbent and involve thrusting and imbrication of basement with slices of oceanic metavolcanics and metasediments. The Archean Tanzania Craton is the foreland to the mobile belt. According to Shackleton and Key and co-workers, crustal thickening occurred in the suture zone, and west-verging thrust faults emplaced younger rocks onto the craton's eastern margin.

Gravity anomalies over Archean-Proterozoic sutures

A characteristic Bouguer gravity anomaly is found over many collisional sutures worldwide. 
The best studied gravity anomalies over Archean-Proterozoic sutures are from the margin of the Superior Province in Canada (Thomas and Tanner, 1975; Kearey, 1976; Gibb and Thomas, 1976, 1977; Thomas and Gibb, 1977; Thomas and Kearey, 1980; Mukhopadhyay and Gibb, 1981; Gibb et al., 1983). Other gravity anomalies over Archean-Proterozoic sutures which have been studied in some detail are from Australia (Mathur, 1974; Wellmann, 1978), India (Subrahmanyam, 1978) and West Africa (Blot et al., 1962; Louis, 1978; Black et al., 1979).

Figure $2 \mathrm{a}$ shows representative gravity profiles over three different sutures in Canada, Australia, and India. The characteristic features of suture anomalies are a gravity "low" over the cratonmobile belt contact and a gravity "high" over the mobile belt. Wavelengths are usually several hun-

(a)
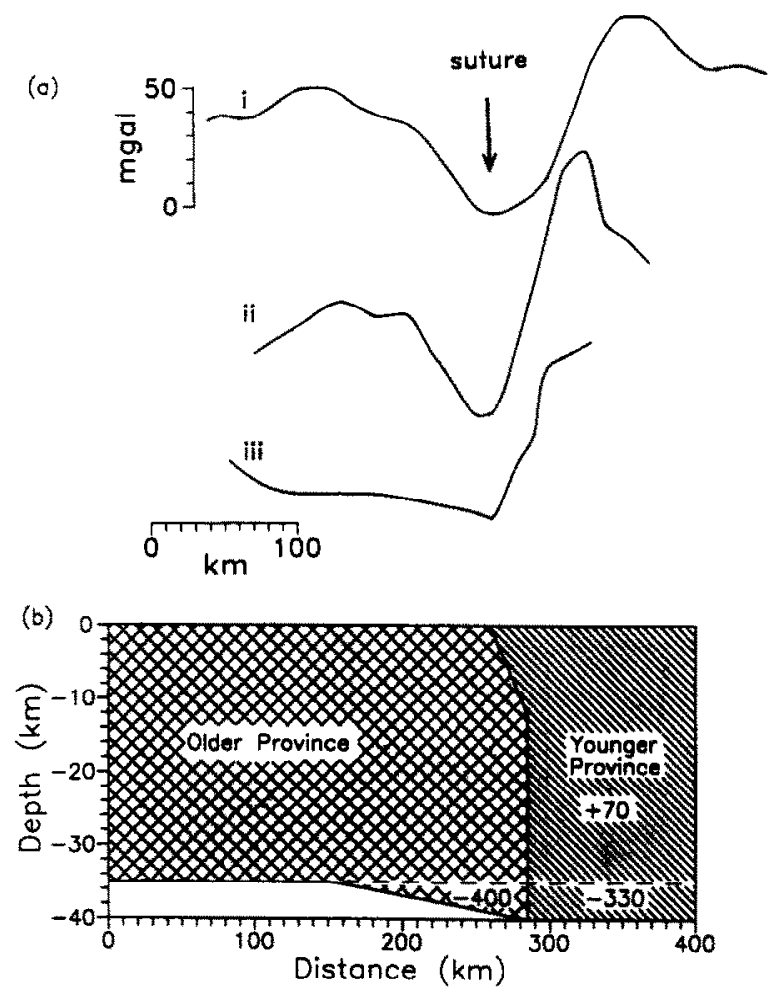

Fig. 2. Suture gravity anomalies and model. a. Bouguer gravity anomalies: (i) Cape Smith fold belt, Canada (Mukhopadhyay and Gibb, 1981), (ii) Fraser Range, Australia (Mathur, 1974), (iii) Eastern Ghats, India (Subrahmanyam, 1978). b. Gravity model for sutures around the margin of the Superior Province in Canada (after Gibb and Thomas, 1976); numbers give density contrasts in $\mathrm{kg} / \mathrm{m}^{3}$. dred kilometers, and amplitudes of $50 \mathrm{mGal}$ or more are frequently observed. Although suture anomalies worldwide have these characteristic features, wavelengths and amplitudes can vary considerably between anomalies from different sutures, as well as within individual sutures.

To explain the anomalies found in Canada, Gibb and Thomas (1976) developed a simple gravity model which has become the type model used for interpreting suture anomalies worldwide (Fig. 2b). In this model the gravity "low" results from a depressed Moho beneath the suture. The crustal "root" is about $5 \mathrm{~km}$ thick and has a density contrast of up to $400 \mathrm{~kg} / \mathrm{m}^{3}$. The positive anomaly over the younger province is caused by denser material in the crust. Modelled density contrasts between the older and younger crustal blocks can be as much as $100 \mathrm{~kg} / \mathrm{m}^{3}$.

The interpretation of the gravity "low" in terms of thickened crust beneath the suture is strongly supported by seismic studies that have detected $5-10 \mathrm{~km}$ increases in crustal thickness beneath various sutures around the Superior Province (Gibb et al., 1983, and references therein; Mereu et al., 1986; Green et al., 1988). The origin of the gravity "high" over the younger block is more controversial. Part of the gravity "high" may result from fragments of oceanic crust accreted to the younger block during suturing. Kearey (1976) explained the positive anomaly by an undulation in the Conrad discontinuity. Alternatively, Fountain and Salisbury (1981) proposed that thrusting along the suture brings slices of higher density lower crustal rocks nearer to the surface. Whatever the origin may be, the common occurrence of a gravity "high" over the younger block requires the younger crust to have a higher average density than the adjacent older crust.

\section{Gravity data and model}

Some 12,000 point Bouguer gravity anomalies define the long-wavelength anomaly over western Kenya and northeastern Tanzania (Fig. 3 ). Four representative gravity profiles across this region are displayed in Figure 4 and show the major features of the long wavelength anomaly. Shown in Figure 4 are point anomalies from up to $15 \mathrm{~km}$ 
on either side of the profile, and solid line profiles constructed by gridding the point anomalies at a $2.5 \mathrm{~km}$ interval, and then filtering to remove wavelengths less than $50 \mathrm{~km}$. The long-wavelength Bouguer anomaly, as illustrated by these profiles, lies roughly between $33.5^{\circ} \mathrm{E}$ and $37.5^{\circ} \mathrm{E}$, is about $400-500 \mathrm{~km}$ wide, and has an amplitude of several tens of milliGals.

We have suggested above that crustal structures along the craton-mobile belt boundary give rise to some of the observed Bouguer anomaly over western Kenya and northeastern Tanzania, because (1) there is geological evidence that the
Mozambique Belt is a continent-continent collision zone, and (2) characteristic suture gravity anomalies are commonly found over ArcheanProterozoic sutures elsewhere in the world. Additionally, there is another line of reasoning, illustrated in Figure 4, to support our interpretation. The Tanzania Craton-Mozambique Belt contact and the Kenya Rift are marked on each gravity profile in Figure 4. It is evident from this figure that the long wavelength Bouguer anomaly is characterized by at least two minima, one over the craton-mobile belt boundary, and one or more over the rift valley. The spatial correlation

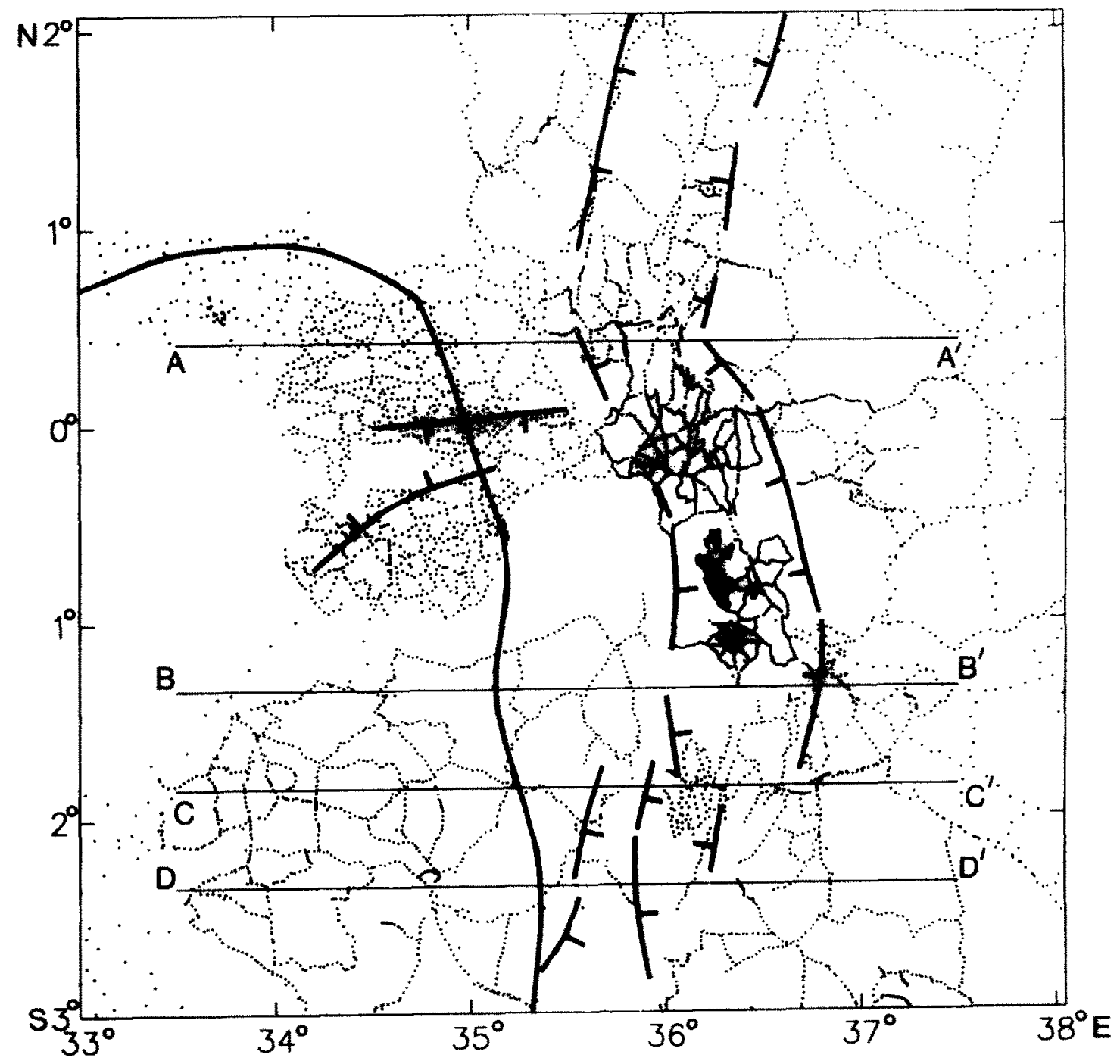

Fig. 3. Location of gravity measurements (dots) in western Kenya and northeastern Tanzania. The margin of the Tanzania Craton and the major rift faults as shown in Fig. 1 are highlighted for orientation. Profile lines give the location of the gravity profiles in Fig. 4. 


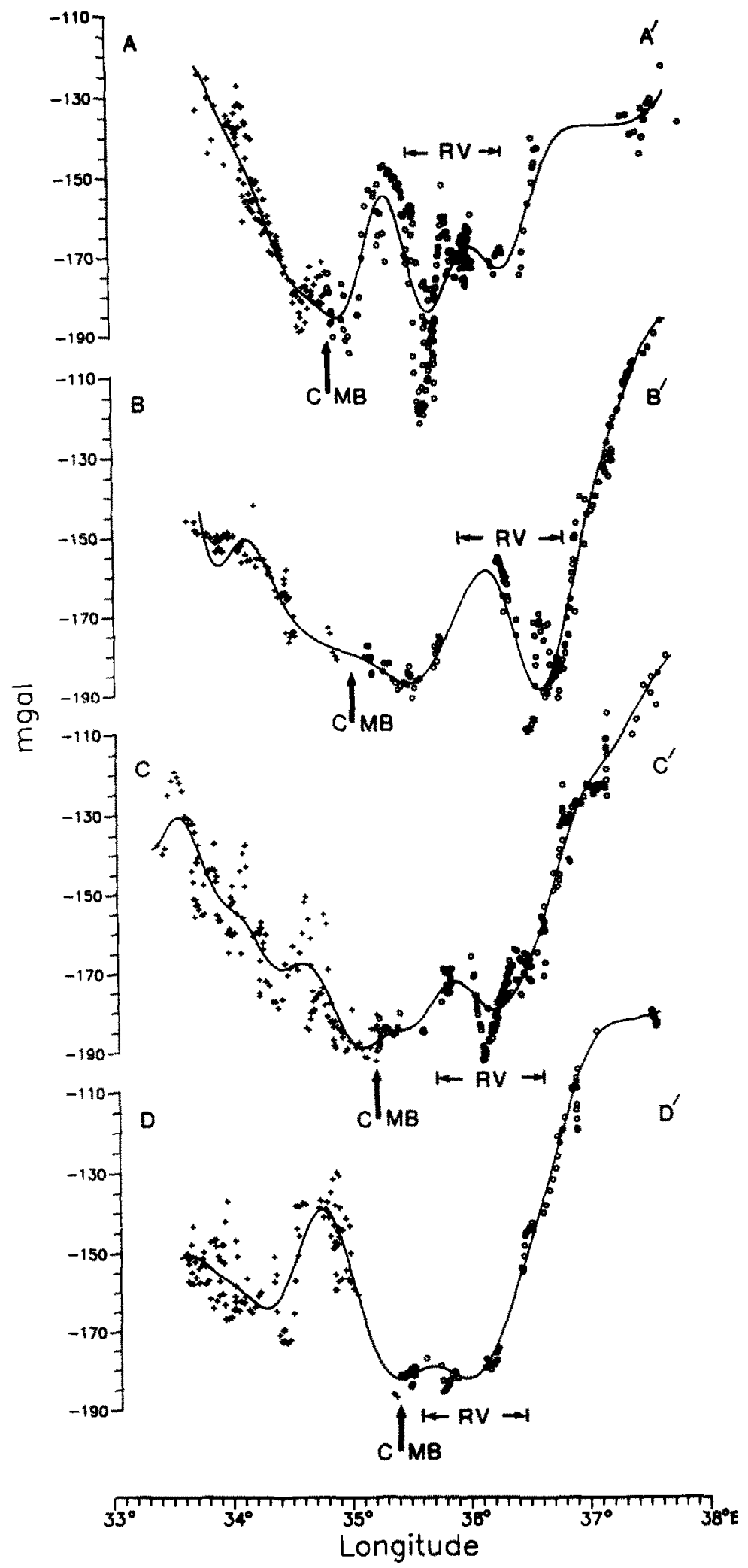

Fig. 4. Gravity profiles over western Kenya and northeastern Tanzania. Profile locations are shown in Fig. 3. The small crosses and circles are point anomalies from the Tanzania Craton and Mozambique Belt, respectively. The solid line represents a filtered profile excluding wavelengths shorter than $50 \mathrm{~km}$. The bold arrow marks the Tanzania Craton-Mozambique Belt boundary. $C=$ Tanzania Craton, $M B=$ Mozambique Belt, $R V=$ Kenya Rift Valley. 
between the craton margin and a gravity minimum clearly suggests that structures beneath the craton margin contribute to the observed anomaly. The gravity minimum along the craton margin is consistently observed between $3.0^{\circ} \mathrm{S}$ and $0.8^{\circ} \mathrm{N}$, except where the Kavirondo Rift intersects the craton margin (Fig. 1). There the gravity low arising from the suture is likely obscured by the gravimetric effects of crustal structures related to the Kavirondo Rift (Fairhead and Walker, 1979).

The boundary between the Tanzania Craton and Mozambique Belt is fairly well established to the south of the Kenya Rift in Tanzania, and it is of interest to know if a "suture" anomaly is apparent in this region where there is no rift graben. Unfortunately, the gravity coverage south of the Kenya Rift is sparse and insufficient to define a coherent gravity pattern over the cra- ton-mobile belt boundary. The data suggest that there may be a gravity "low" over the suture, as observed to the north in Kenya, but it is not adequately resolved with the available data.

Our new gravity model (Fig. 5) is illustrated for a gravity profile at $0.4^{\circ} \mathrm{N}$ (profile $A-A^{\prime}$, Fig. 4). To calculate the gravity signal of our model, we used a 2-D algorithm for the gravitational attraction of right rectangular prisms (Nagy, 1966). Our model has two components, a "suture" and a "rift". The "suture" follows the Gibb and Thomas (1976) model, and comprises a low-density crustal root beneath the craton-mobile belt boundary and higher-density crust in the mobile belt. The "rift" component of the model has three elements: (1) an axial low-density zone about $100 \mathrm{~km}$ wide in the mantle lithosphere; (2) a high-density intrusion in the lower crust; and
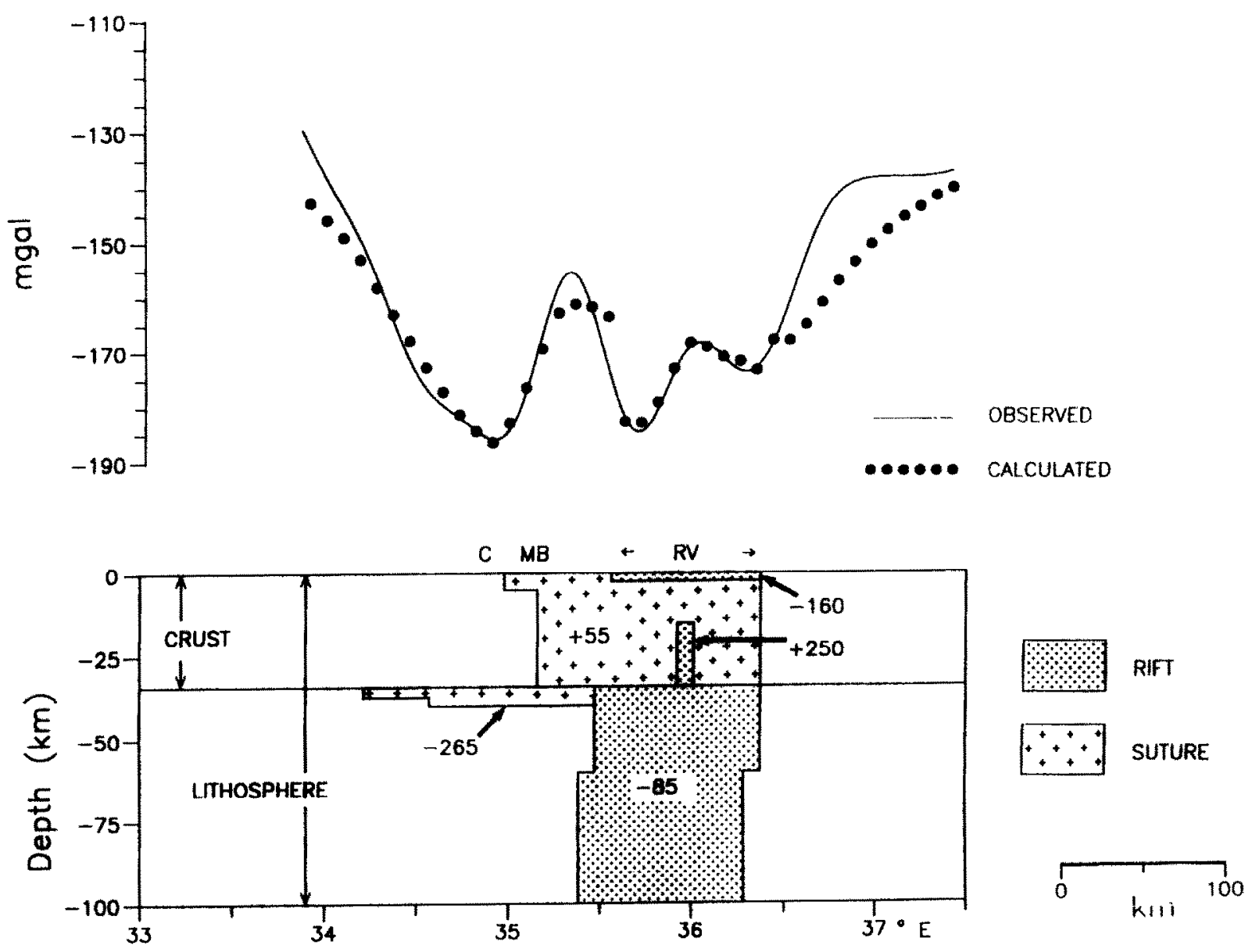

Fig. 5. Gravity model for profile $A-A$ ' (Fig. 4), showing the "rift" and "suture" components. Symbols are the same as in Fig. 4. Numbers give density contrasts in $\mathbf{k g} / \mathrm{m}^{3}$. 
(3) a shallow rift basin filled with low-density sediments and volcanics. Starting with the Gibb and Thomas suture model and a low-density zone in the mantle beneath the rift, the model geometry and densities were adjusted on a trial and error basis until a satisfactory fit between the observed and calculated anomaly was obtained. There is good agreement between the calculated and the observed gravity anomaly over the center part of the model and the western edge, but on the eastern side of the model there is greater departure between the calculated and observed anomalies. However, the eastern side of the profile is not as well constrained by measurements (see profile $A-A^{\prime}$, Fig. 4), and therefore the departures may be somewhat artificial.

\section{Discussion}

The geometry of the crustal and mantle blocks comprising our model and their densities are non-unique; many alternative geometries and densities could produce an equally satisfactory fit between the calculated and observed anomalies. However, the general features of our model are consistent with seismic models and density measurements of surface rocks. There are several seismic investigations of the Kenya Rift which provide independent constraints on crustal and upper mantle structure beneath the rift valley. The low-density zone in our model, which is essentially confined to the width of the rift valley, is consistent with models of P-wave travel-time delays showing a low-velocity zone localized in the area beneath the rift valley: models by Maguire and Long (1976) and Long and Backhouse (1976) show that the low-velocity zone beneath the western flank of the rift does not extend significantly beyond the rift's western margin, and a complementary study by Savage and Long (1985) suggests that the low-velocity zone is mainly confined to the area directly beneath the rift. More recently, Green et al. (1991) presented a three-dimensional image of the velocity structure beneath the central Kenya Rift from inverting P-wave travel-time residuals. This image shows a steep-sided low-velocity body beneath the rift, confirming the earlier models of travel-time delay data. The low-density zone in our model also shifts slightly to the west with depth, consistent with recent studies suggesting that the low-velocity zone also shifts somewhat to the west with depth (Dahlheim et al., 1989; Green et al., 1991).

There is supportive evidence from seismic refraction studies for the shallow rift basin in our model. The 1991 KRISP cross-rift profile (KRISP working party, 1991) shows that the rift fill is about 2-3 km thick below Lake Baringo, which is approximately at the same latitude as profile $A-A^{\prime}$ in Figure 4. The velocity of the rift fill is about $1.4 \mathrm{~km} / \mathrm{s}$ slower than the basement velocity, thus suggesting that its density is lower than the basement density. Density measurements on rift volcanics also suggest low-density material in the rift valley. The floor of the Kenya Rift south of about $1.0^{\circ} \mathrm{N}$ is covered predominantly by trachytes. The mean density of seven trachyte samples from the rift valley is $2550 \mathrm{~kg} / \mathrm{m}^{3}$ (Fairhead, 1976), considerably lower than a mean density of $2640 \mathrm{~kg} / \mathrm{m}^{3}$ reported for a number (13) of rock samples from the Mozambique Belt (Fairhead, 1976).

Evidence for a crustal density contrast between the Mozambique Belt and the Tanzania Craton is also provided by the KRISP 1991 cross-rift seismic refraction profile; the upper crustal velocity of the Tanzania Craton just west of the craton-mobile belt boundary is $5.9 \mathrm{~km} / \mathrm{s}$, but is $6.0-6.1 \mathrm{~km} / \mathrm{s}$ in the Mozambique Belt to the east of the craton-mobile belt contact. The higher crustal velocity in the mobile belt suggests a slightly higher crustal density in the mobile belt relative to the craton, as we show in our model (Fig. 5). Moreover, the average density of several granitic rock samples (22) from the Tanzania Craton $\left(2620 \mathrm{~kg} / \mathrm{m}^{3}\right)$ (Darracott, 1972) is slightly lower than the average density of the 13 Mozambique Belt rock samples $\left(2640 \mathrm{~kg} / \mathrm{m}^{3}\right.$ ) (Fairhead, 1976). Although the difference in these mean densities is somewhat lower than in our model (Fig. 5), the density measurements are suggestive of slightly higher-density mobile belt crust relative to the cratonic crust. Additionally, the KRISP 1991 cross-rift refraction profile provides evidence for a modest crustal root beneath the suture. The KRISP velocity model shows the Moho 
increasing in depth from about $36-37 \mathrm{~km}$ beneath the craton to about $40 \mathrm{~km}$ beneath the suture.

In contrast to the other general features of our model, the lower crustal intrusion beneath the rift has not been clearly imaged with seismic techniques (KRISP working group, 1987; Henry et al., 1990; KRISP working party, 1991). But, if the crustal intrusion is as small as our model suggests, and if it does not penetrate into the upper crust, it may perhaps be difficult to detect.

As briefly mentioned in the introduction, previous studies have modeled the long-wavelength Bouguer anomaly largely with low-density (hot) material in the upper mantle. We show two representative examples of such models in Figure 6. Figure 6a is a model by Fairhead (1976) in which the entire gravity anomaly arises from an extensive zone of lithospheric thinning, located not only beneath the rift, but also extending more than $100 \mathrm{~km}$ to the west of the rift beneath unfaulted regions of the Mozambique Belt and Tanzania Craton. An alternative model (Baker and Wohlenberg, 1970), which does not cover as broad an area as Fairhead's model, is shown in Figure $6 \mathrm{~b}$. In this model the hot low-density region in the lithosphere is confined to a narrower zone beneath the rift, and in order to account for the long-wavelength nature of the anomaly, a thin, continuous low-density sheet is placed at the surface. Baker and Wohlenberg attribute the lowdensity surface material to Tertiary volcanics which are present along most of their profile. However, in many areas to the west of the rift Precambrian basement is exposed, and so a volcanic source of low-density material cannot be used to explain the gravity anomaly in these areas.

Our model has some similarities to and differences from the models illustrated in Figure 6a and b. For comparison, our model is shown in Figure 6c. It is similar to the Baker-Wohlenberg model in that the size and shape of the low-density zone in the mantle lithosphere are about the same. Our model differs from theirs in three ways: (1) the lower crustal intrusion beneath the rift basin is about half the size of theirs; (2) there is no low-density sheet at the surface extending beyond the rift valley; and (3) there are crustal structures in the suture zone. Compared to Fairhead's model, our model has a narrower, more confined low-density zone in the mantle lithosphere, and it includes crustal structures in both the rift valley and the suture zone, whereas the crust in Fairhead's model is uniform.

$\Lambda$ further issue is the isostatic balance of the Gibb and Thomas "suture" model and our "suture" model in Figure 5. There is little topography over the Canadian sutures, and, therefore, in the Gibb and Thomas model (Fig. 2b) local isostatic equilibrium is achieved for the crustal blocks comprising the mobile belt by balancing the positive buoyancy of the crustal root with denser material above the root. The cratonic crustal root adjacent to the craton-mobile belt boundary, however, is not balanced by denser cratonic crustal material. This part of the Gibb and Thomas model is not in isostatic equilibrium. The $400-500 \mathrm{~km}$ wavelength anomaly in western Kenya and northeastern Tanzania (i.e. both the "rift" and "suture" anomaly) is associated with a broad region of crustal uplift (the Kenya dome). Thus, in contrast to the Canadian suturcs, it appears that at least some of the crustal density contrasts in the Tanzania Craton-Mozambique Belt suture may be topographically compensated.

A possible explanation for the difference in topography between the two sutures is that the lithosphere in East Africa because of rifting is fractured and thus weaker than the Canadian lithosphere. In Canada, the lithosphere probably has sufficient elastic strength to support the buoyancy force of the cratonic crustal root. Bechtel et al. (1990) estimate the effective elastic plate thickness of the Canadian shield to be on the order of $100 \mathrm{~km}$. The lateral extent of the crustal root is $\sim 100 \mathrm{~km}$, and a load of this size will have little if any topographic compensation on an elastic plate $100 \mathrm{~km}$ thick (Turcotte and Schubert, 1982, p. 123). However, if the East African lithosphere is broken at the rift, the elastic strength of the East African plate will be reduced significantly (Turcotte and Schubert, 1982, p. 127), and may not be sufficient to support the buoyancy force of the cratonic crustal root. Hence, crustal uplift may develop over the suture. 

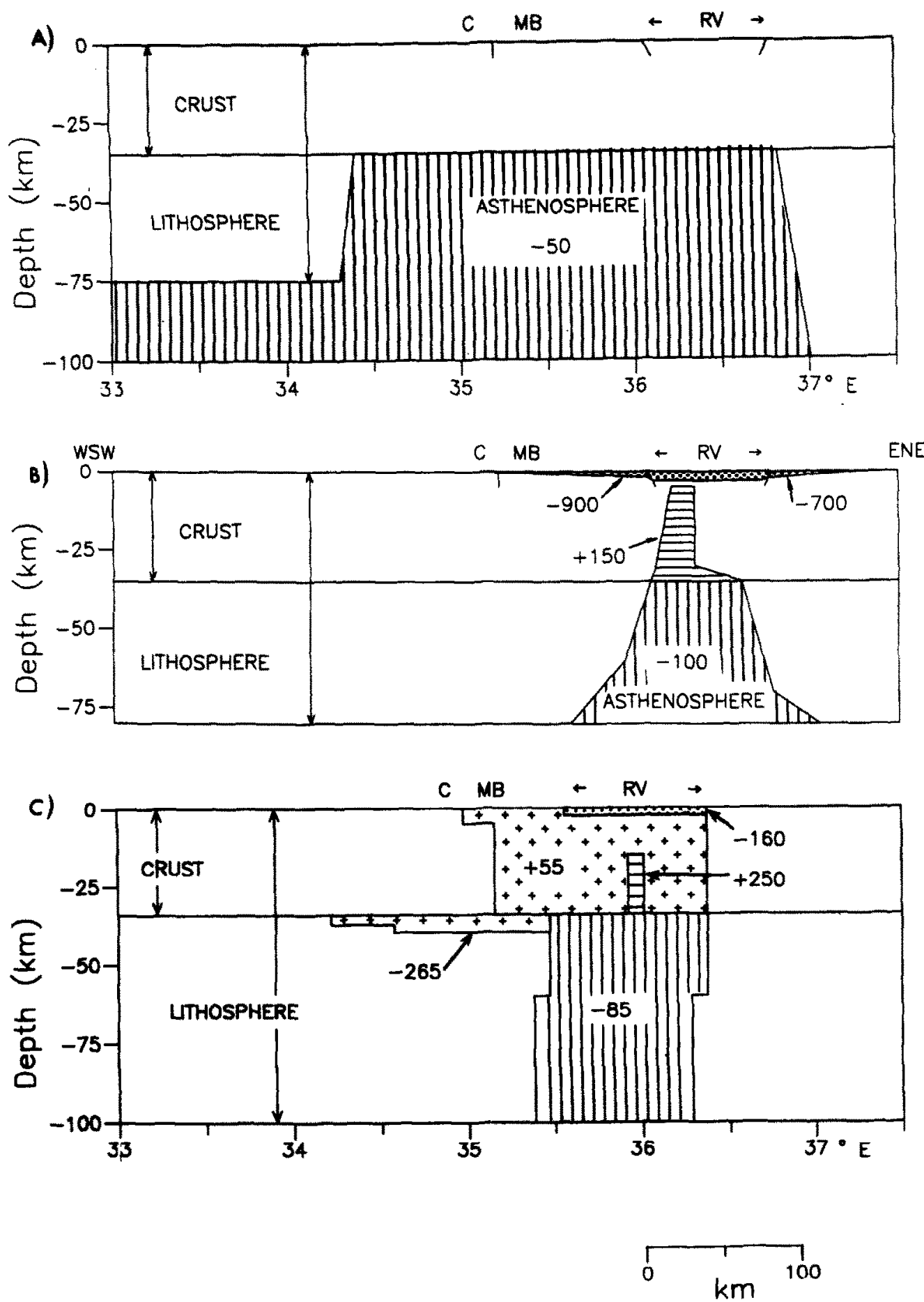

Fig. 6. Published gravity models for the Kenya Rift. a. A model by Fairhead (1976) at $1.8{ }^{\circ} \mathrm{S}$ showing lithospheric thinning beneath the rift valley, as well as beneath the Mozambique Belt and Tanzania Craton to the west of the rift. b. A model by Baker and Wohlenberg (1970) at approximately the equator showing thinning localized beneath the rift and a low-density sheet at the surface. c. Gravity model presented in this paper. Symbols are the same as in Fig. 4; numbers give density contrasts in $\mathrm{kg} / \mathrm{m}^{3}$. 
In summary, we propose that the Bouguer anomaly over the Kenya Rift and surrounding region may be a combination of a "suture" anomaly, which arises from crustal structures developed along the Archean craton margin, and a "rift" anomaly, which derives from crustal structures and a low-density zone about $100 \mathrm{~km}$ wide in the mantle lithosphere beneath the rift valley. If our hypothesis is correct, low-density material is confined to a much narrower zone in the mantle lithosphere than hypothesized by Fairhead (1976) and shown in Figure 6a, and the density contrast associated with this low-density zone may be somewhat smaller than the density contrast proposed by Baker and Wohlenberg (1970) and shown in Figure $6 \mathrm{~b}$. The presence of a low-density zone in the upper mantle that is confined to the width of the rift valley is important for understanding continental rift development because it suggests that during the early stages of continental break-up there is no large-scale perturbation of the base of the lithosphere well away from the margins of rift valleys.

\section{Acknowledgments}

This research has been supported in part by the US National Science Foundation grant EAR8706599. We thank the US Defense Mapping Agency for providing gravity measurements, Kevin Furlong for beneficial discussions, and Derek Fairhead and Ron Girdler for constructive reviews.

\section{References}

Baker, B.H. and Wohlenberg, J., 1970. Structure and evolution of the Kenya Rift Valley. Nature, 229: 538-542.

Baker, B.H., Mohr, P.A. and Williams, L.A.J., 1972. The geology of the Eastern Rift System of Africa. Geol. Soc. Am. Spec. Pap., 136, 67 pp.

Bechtel, T.D, Forsyth, D.W. and Swain, C., 1987. Mechanisms of isostatic compensation in the vicinity of the East African rift, Kenya. Geophys. J.R. Astron. Soc., 90: 445-465.

Bechtel, T.D., Forsyth, D.W., Sharpton, V.L. and Grieve, R.A.F., 1990. Variations in effective elastic thickness of the North American lithosphere. Nature, 343: 636-638.

Black, R., Caby, R., Moussine-Pouchkine, A., Bayer, R., Bertad, J.M., Boullier, A.M., Fabre, J. and Lesquer, A.,
1979. Evidence for late Precambrian plate tectonics in West Africa. Naturc, 278: 223-227.

Blot, C., Crenn, Y., Rechenmann, R., 1962. Elements apportes par la gravimetrie a la connaissance de la tectonique profonde du Senegal. C.R. Acad. Sci. Paris, 254: 1131-1133.

Bullard, E.C., 1936. Gravity measurements in East Africa. Philos. Trans. R. Soc. London Ser. A, 235: 445-531.

Cahen, L., Snelling, N.J., Delhal, J. and Vail, J.R., 1984. The Geochronology and Evolution of Africa. Oxford Univ. Press, New York, NY, 512 pp.

Dahlheim, H., Davis, P. and Achauer, U., 1989. Teleseismic investigation of the East African Rift-Kenya. J. Afr. Earth Sci., 8: 461-470.

Darracott, B.W., 1972. Gravity and Magnetic Surveys of the Speke Gulf, Serengeti and Mara Regions, and Their Relevance to Rifting in East Africa. Ph.D. Thesis. Univ. Newcastle upon Tyne, $175 \mathrm{pp}$.

Darracott, B.W., 1974. The structure of Speke Gulf, Tanzania, and its relation to the East African Rift System, Tectonophysics, 23: 155-175.

Darracott, B.W., Fairhead, J.D. and Girdler, R.W., 1972. Gravity and magnetic surveys in northern Tanzania and southern Kenya. Tectonophysics, 15: 131-141.

Ebinger, C.J., 1989. Tectonic development of the western branch of the East African rift system. Geol. Soc. Amer. Bull., 101: 885-903.

Ebinger, C.J., Bechtel, T.D., Forsyth, D.W. and Bowin, C.O., 1989. Effective elastic plate thickness beneath the East African and Afar plateaus and dynamic compensation of the uplifts. J. Geophys. Res., 94: 2883-2901.

Fairhead, J.D., 1976. The structure of the lithosphere beneath the eastern rift, East Africa, deduced from gravity studies. Tectonophysics, 30: 269-298.

Fairhead, J.D. and Walker, P., 1979. A detailed gravity study of the crustal structure associated with the Kavirondo rift valley, East Africa. In: Geodynamic Evolution of the Afro-Arabian Rift System. Accad. Naz. Dei Lincei, Rome, pp. 99-109.

Fountain, D.M., Salisbury, M.H., 1981. Exposed cross-section through the continental crust: implications for crustal structure, petrology, and evolution. Earth Planet. Sci. Lett., 56: $263-277$

Gibb, R.A. and Thomas, M.D., 1976. Gravity signature of fossil plate boundaries in the Canadian Shield. Nature, 262: 199-200.

Gibb, R.A. and Thomas, M.D., 1977. The Thelon front: a cryptic suture in the Canadian shield? Tectonophysics, 38 : 211-222.

Gibb, R.A., Thomas, M.D., Lapointe, P. and Mukhopadhay, M., 1983. Geophysics of proposed Proterozoic sutures in Canada. Precambrian Res., 19:349-384.

Girdler, R.W., 1975. The great negative Bouguer anomaly over Africa. EOS Trans. Amer. Geophys. Union, 56: 516519.

Girdler, R.W., Fairhead, J.D., Searle, R.C. and Sowerbutts, 
W.T.C., 1969. The evolution of rifting in Africa. Nature, 224: 1178-1182.

Green, A.G., Milkereit, B., Davidson, A., Spencer, C., Hutchinson, D.R., Cannon, W.F., Lee, M.W., Agena, W.F., Behrendt, J.C. and Hinze, W.J., 1988. Crustal structure of the Grenville front and adjacent terranes. Geology, 16: 788-792.

Green, W.V., Achauer, U. and Meyer, R.P., 1991. A three-dimensional seismic image of the crust and upper mantle beneath the Kenya rift. Nature, 354: 199-203.

Henry, W.J., Mechie, J., Maguire, P.K.H., Khan, M.A., Prodehl, C., Keller, G.R. and Patel, J., 1990. A seismic investigation of the Kenya Rift Valley. Geophys. J. Int., 100: 107-130.

Kearey, P., 1976. A regional structural model of the Labrador Trough, northern Quebec, from gravity studies, and its relevance to continent-continent collision in the Precambrian. Earth Planet. Sci. Lett., 28: 371-378.

Key, R.M., Charsley, T.J., Hackman, B.D., Wilkinson, A.F. and Rundle, C.C., 1989, Superimposed upper Proterozoic collision-controlled orogenies in the Mozambique orogenic belt of Kenya. Precambrian Res., 44: 197-225.

Khan, M.A. and Mansfield, J., 1971. Gravity measurements in the Gregory Rift. Nature, 229: 72-75.

KRISP working group, 1987. Structure of the Kenya rift from seismic refraction. Nature, 325: 239-242.

KRISP working party, 1991. Large-scale variation in lithospheric structure along and across the Kenya rift. Nature, 354: 223-227.

Long, R.E. and Backhouse, R.W., 1976. The structure of the western flank of the Gregory Rift, part 11, the mantle. Geophys. J.R. Astron. Soc., 44: 677-688.

Louis, P., 1978. Gravimetrie et geologie en Afrique occidentale et centrale. Mem. Bur. Rech. Geol. Min., 91: 53-61.

Maguire, P.K.H. and Long, R.E., 1976. The structure of the western flank of the Gregory rift (Kenya), Part I, the crust. Geophys. J.R. Astron. Soc., 44: 661-675.

Masson-Smith, D. and Andrew, E.M., 1962. Gravity meter primary station net in East and Central Africa. Geophys. J.R. Astron. Soc., 7: 65-85.

Mathur, S.P., 1974. Crustal structure in southwestern Australia from seismic and gravity data. Tectonophysics, 24: 151-182.

Mereu, R.F., Wang, D., Kuhn, O., Forsyth, D.A., Green, A.G., Morel, P., Buchbinder, G.C.R., Crossley, D., Schwarz, E., duBerger, R., Brooks, C. and Clowes, R., 1986. The 1982 COCRUST seismic experiment across the
Ottawa-Bonnechere graben and Grenville front in Ontario and Quebec. Geophys. J.R. Astron. Soc., 84: 491-514.

Mukhopadhyay, M. and Gibb, R.A., 1981. Gravity anomalies and deep structure of eastern Hudson Bay. Tectonophysics, 72: 43-60.

Nagy, D., 1966. The gravitational attraction of a right rectangular prism. Geophysics, 31: 362-371.

Savage, J.E.G. and Long, R.E., 1985. Lithospheric structure beneath the Kenya Dome. Geophys. J.R. Astron. Soc., 82: 461-477.

Searle, R.C., 1970, Evidence from gravity anomalies for thinning of the lithosphere beneath the rift valley in Kenya. Geophys. J.R. Astron. Soc., 21: 13-21.

Shackleton, R.M., 1986. Precambrian collision tectonics in Africa. In: M.P. Coward and A.C. Ries (Editors), Collision Tectonics. Blackwell, Oxford, pp. 329-349.

Sowerbutts, W.T.C., 1969. Crustal structure of the East African Plateau and Rift Valleys from gravity measurements. Nature, 223: 143-146.

Subrahmanyam, C., 1978. On the relation of gravity anomalies to geotectonics of the Precambrian terrains of the south Indian Shield. J. Geol. Soc. India, 19: 251-263.

Swain, C.J. and Khan, M.A., 1978. Gravity measurements in Kenya. Geophys. J.R. Astron. Soc., 53: 427-429.

Swain, C.J., Khan, M.A., Wilton, T.J., Maguire, P.K.H. and Griffiths, D.H., 1981. Seismic and gravity surveys in the Lake Baringo-Tugen Hills area, Kenya rift valley. J. Geol. Soc. London, 138: 93-102.

Thomas, M.D. and Gibb, R.A., 1977. Gravity anomalies and deep structure of the Cape Smith foldbelt, northern Ungava, Quebec. Geology, 5: 169-172.

Thomas, M.D. and Tanner, J.G., 1975. Cryptic suture in the eastern Grenville province. Nature, 256: 392-394.

Thomas, M.D. and Kearey, P., 1980. Gravity anomalies, block-faulting and Andean-type tectonism in the eastern Churchill Province. Nature, 283: 61-63.

Turcotte, D.L. and Schubert, G., 1982. Geodynamics. Wiley, New York, NY, $450 \mathrm{pp}$.

Wellmann, P., 1978. Gravity evidence for abrupt changes in the mean crustal density at the junction of Australian crustal blocks. Aust. Bur. Miner. Resour. Geol. Geophys. Bull, 3: 153-162.

Wohlenberg, J., 1975. The structure of the lithosphere beneath the East African Rift zones from interpretation of Bouguer anomalies. In: A. Pilger and A. Rosler (Editors), Afar Depression of Ethiopia, 2. Schweizerbart, Stuttgart, pp. $125-130$. 